\title{
History of Pearling in La Paz Bay, South Baja California
}

By Micheline Cariño and Mario Monteforte

The history of Baja California has been closely tied to the exploitation of pearls since the 16th century. Using rudimentary diving techniques for most of this era, European and Mexican entrepreneurs recovered vast anounts of fine, dark pearls from this region. However, years of overfishing inevitably led to decades when the oyster beds were all but barren. Introduction of the diving suit in the 19th century extended the depth of the beds that could be fished, but overexploitation continued largely unchecked. Cultivation of the pearl oyster Pinctada mazatlanica by Gastón Vives, between 1903 and 1914, greatly slowed exhaustion of the natural stock. His company, CCCP, represented the world's first large-scale cultivation of pearl oysters, and many of Vives's discoveries are used today in renewed pearl-oyster cultivation and pearl-culturing activities in Baja California.

ABOUT THE AUTHORS
Dr. Carino is professor and researcher in history
at the Universidad Autónoma de Baja California
Sur, Km 5.5 Carretera al sur, La Paz B.C.S.
23000, Mexico. Dr. Monteforte is lead scientist of
the research group Grupo Ostras Perleras, at the
Centro de Investigaciones Biológicas del
Noroeste (CIBNOR). S.C., Km 2 Carretera a San
Juan de La Costa, El Comitán, La Paz B.C.S.
23000, Mexico.
Acknowledgments: The authors especially thank
the descendants of Don Gastón Vives (Don
Juanito Vives, Doña Yolanda Vives de Barrón,
and Lic. Gastón Barrón Vives), Who donated the
early photographs and provided valuable infor-
mation. In 1987, the senior author conducted a
two-hour interview with J. Vives Lucero, the son
of Gastón Vives, now deceased. We dedicate this
work to the memory of Don Gastón Vives.
Gems \& Gemology, Vol. 31 , No. 2, pp. $88-105$.
C. 1995 Gemological Institute of America

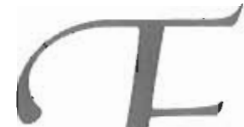

For more than 400 years, the exploitation of pearl resources decisively influenced the history of Baja California, Mexico's northwest peninsula. It represents an important chapter in the world history of pearling. From the 16th century onward, pearls from the Gulf of California have adorned European royalty (figure 1), and many beautiful examples can be found in religious treasures such as those of the cathedrals of Toledo and Seville in Spain. During the 19th and early 20th centuries, mother-of-pearl from Baja California comprised an important portion of the international market for this ornamental material. Yet, surprisingly little has been written about these special Baja Californicl products, either in contemporary accounts dealing with pearl fisheries, cultivation, and pearl-oyster trading, or in the history of the region itself.

Natural pearls of the pearl oyster Pinctada mazatlani$c a$ are typically baroque or semi-baroque, with a silver to dark gray body color and strong overtones of blue, lavender, and green (figure 2). Sometimes a reddish or purple hue can be seen in pearls obtained from oysters established in deeper, colder water, or from older oysters. White or golden hues are rare. The other pearl oyster indigenous to the Baja California region, Pteria sterna, produces smaller but rounder natural pearls, in a wide variety of hues: Purple and violet are in general the most common body colors, with overtones of green, blue, and lavender, similar to those of Pinctada mazatlanica, also seen. Some Pteria sterna will yield up to 10 pearls in a single oyster, but most are no more than a few millimeters in diameter (called moralla, or "coarse sand"). However, we have seen pearls as large as 20 $\mathrm{mm}$ in diameter from Pinctada mazatlanica, with the region once known for its production of larger pearls. Figure 3 illustrates the broad variety of colors, shapes, and sizes in which pearls from Baja California occur.

The first part of this article concerns the fisheries period, from the 15th through the 19th centuries, including the transition from traditional diving methods to large-scale exploitation through the intensive use of compressed-air 
Figure 1. Large dark pearls, undoubtedly from the Spanish empire in the Americas, adorn Queen Isabel of Valois-wife of Spain's King Philip II-in this 1579 oil painting by Juan Pantoja de la Cruz. Vast quantities of pearls were recovered from the Gulf of California and the Pacific Coast of what is now Central and northern South America following Spain's conquest

of the region. Photo

courtesy of the Prado Museum, Madrid, Spain.

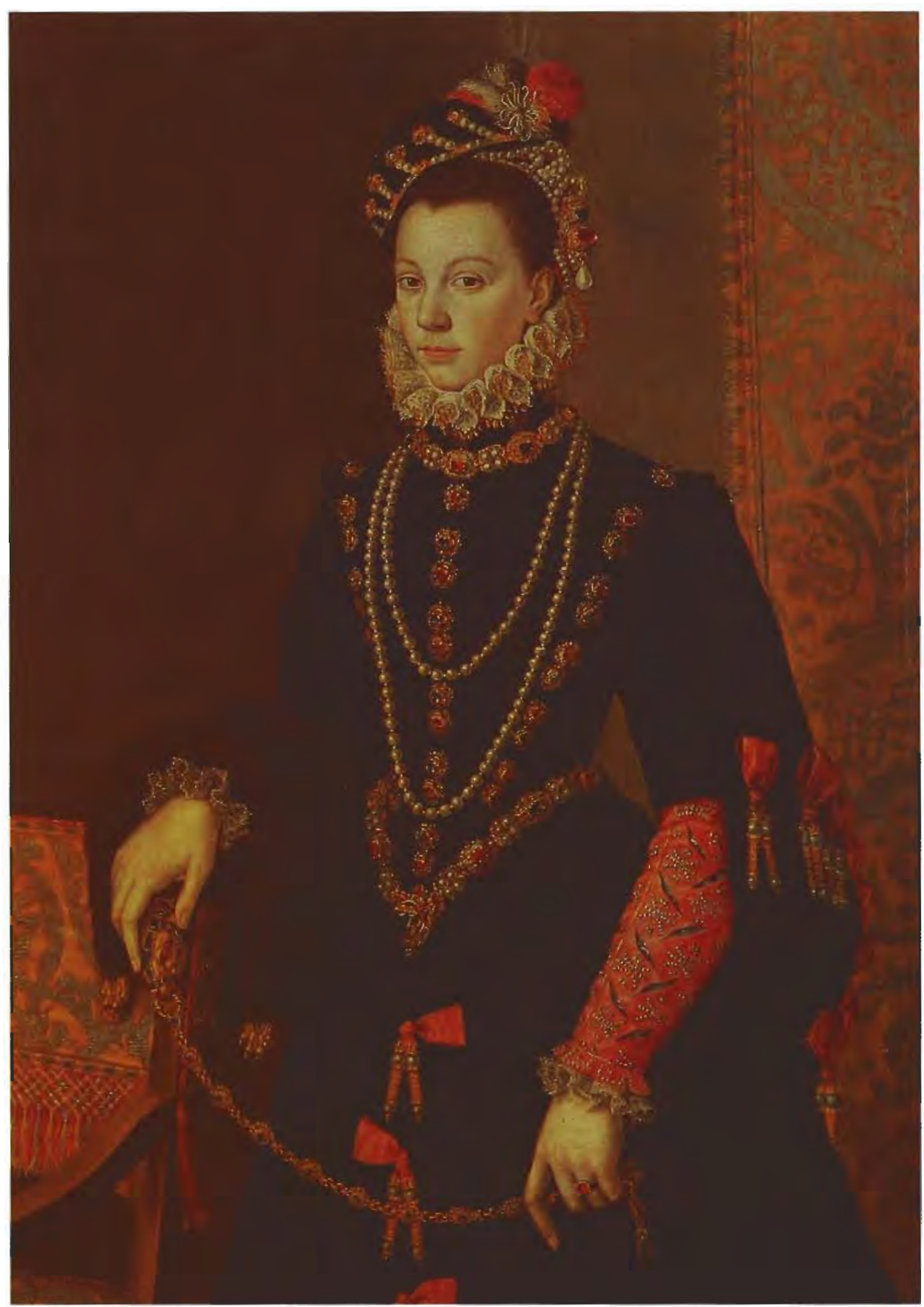

diving gear, such as diving suits. The second part examines Latin America's first aquacultural experiment and the world's first large-scale pearl-oyster cultivation operation (Cariño, 1994), by the Compañía Criadora de Concha y Perla de Baja California (Baja California Archives 1). Founded in 1903 by Gastón Vives, the Compañia Criadora successfully revived pearling and the pearl-oyster industry in southern Baja California in the early 20th century. This second part looks at the technological accomplishments of this operation and its impact on the local region before it became a casualty of the Mexican Revolution of 1910-1917. Today, following decades of overfishing, pollution of the environment, and massive mortalities due to as-yet-unknown causes, these early efforts serve as the basis for a strong research effort to reinstate a pearling industry in La Paz. 


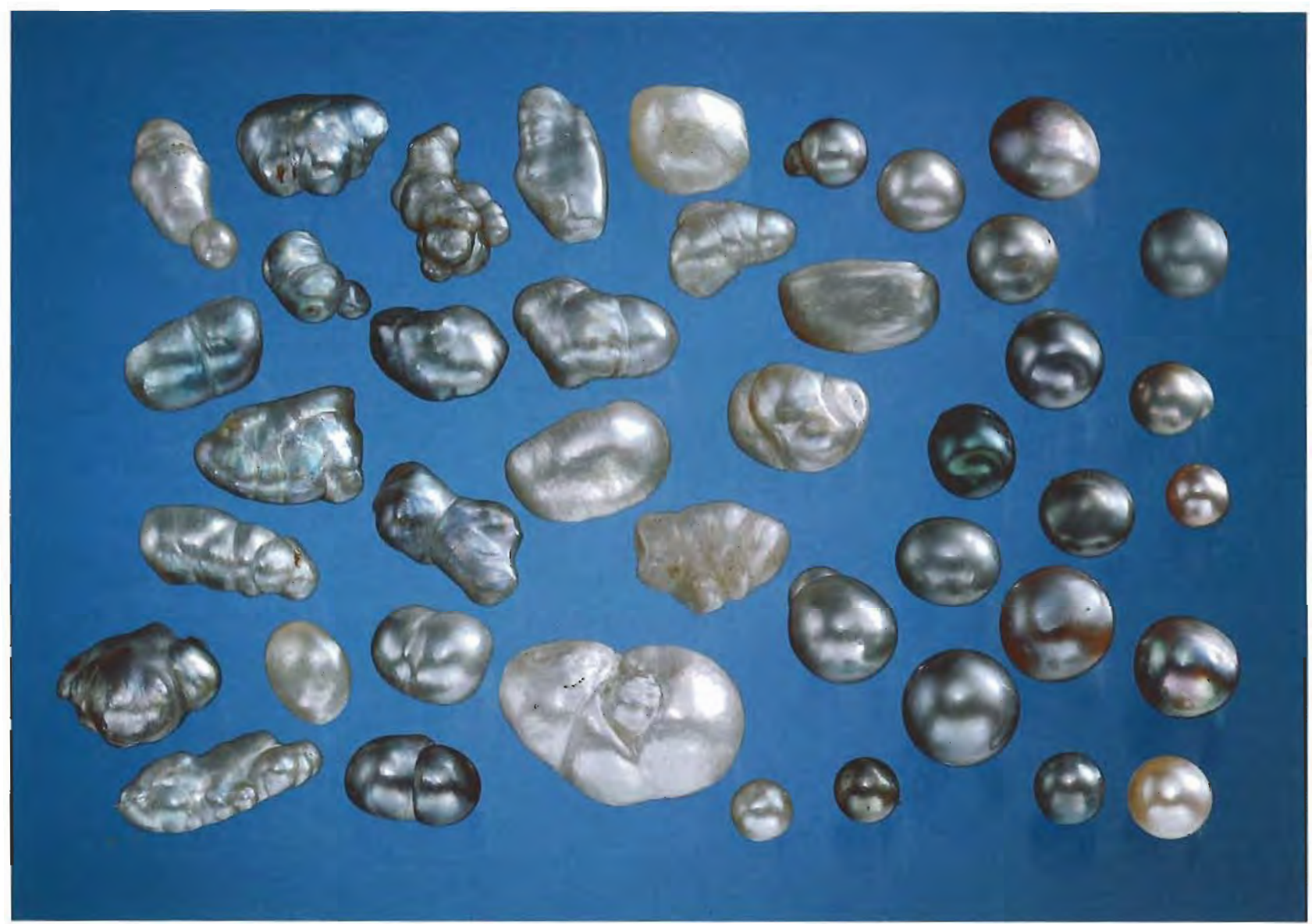

Figure 3. This collection of natural pearls, all reportedly from Baja California, show more of the interesting shapes and colors in which pearls from this area occur. Note that most are baroque, as round pearls from this region are very rare. The largest is $16 \times 11 \mathrm{~mm}$; the smallest is $4 \mathrm{~mm}$. The larger pearls usually are recovered from the large pearl oyster Pinctada mazatlanica, with the smaller pearls recovered from the smaller Pteria sterna. Courtesy of KCB, Santa Monica, California; photo (C) GIA and Harold (4) Erica Van Pelt.

Indias ... there is an island named California inhabited only by beautiful amazons, governed by Queen Calafia, who ride on griffins and wear nothing but jewels made of gold and pearls . ..." (Meade, 1984; del Rio, 1985).

\section{Pearl Oyster Exploitation during the Spanish} Colonial Era. After the expeditions of Hernán Cortés in 1535 and 1539, and those of Viceroy Antonio de Mendoza in 1540, the architects of the Spanish empire recognized the importance of conquering and colonizing this geo-strategic area. In particular, the transpacific route of the Manila galleons made it imperative to establish a port in California. However, early attempts failed, due to the peninsula's aridity and isolation.

In the last two decades of the 16th century, the colonial government evolved a strategy to encourage the mapping and exploration of the Baja
California coast without any cost to the royal treasury. Aware of the greed for pearls that possessed many adventurers, the government granted pearlfishing licenses to those who had the means to search for the needed port. If the license holder failed to show progress, the royal permission to exploit the pearl-oyster grounds was given to someone else.

Beginning with the issuance of the first license in 1586 (Californiana I), pearl fishing was incorporated into the Indias the name given to the Spanish colonies in America) legislation that gave the Spanish Crown monopoly rights to exploit the natural resources of these colonies. These resources could only be exploited with specific permission, which was contingent on payment of the quinto de perlas (one-fifth of the pearls found) to the colonial administration. During the 17 th century, many entrepreneurs acquired pearl fishing 


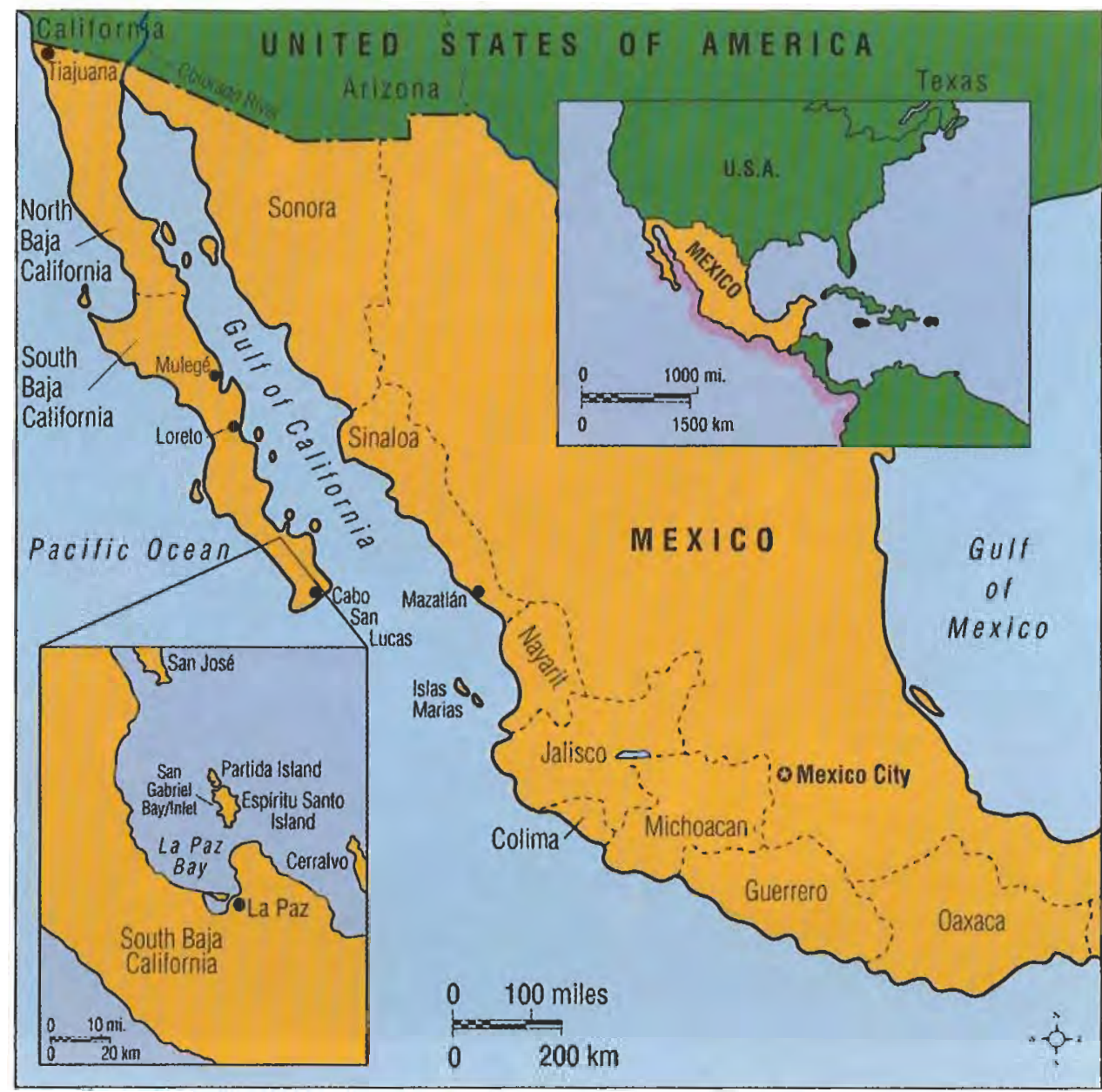

Figure 4. Since the 16th century, the history of Baja California has been tied to the exploitation of pearls, as oceanographic conditions in the Gulf of California support pearl oysters with a high yield of fine natural pearls. The left inset shows a detail of the La Paz area. In the upper right inset, the lavendar line along the coasts of Mexico, Central, and northem South America shows the range of pearl oysters Pinctada mazatlanica and Pteria stema (adapted from Keen, 1971).

licenses and traveled to the Gulf of California in the hope of making their fortunes: This period has become known in regional history as the "Century of the Pearl Explorers" (Mathes, 1973; del Río, 1985). Sebastián Vizcaíno, who mounted two expeditions (in 1596 and 1602), Tomás de Cardona (in 1611), and Pedro Porter y Cassanate (in 1640), were some of the better-known entrepreneurs seduced by the promise of a bounty of beautiful pearls (Mosk, 1927).

These adventurers encountered many obstacles, such as the difficulty of navigating in the Gulf, a precarious subsistence in arid Baja California, dependence on indigenous labor, and even pirate attacks. Because of these obstaclesand their reluctance to pay the full tax (the quinto de perlas - it is difficult to estimate the success of these ventures and the production from their efforts. Nevertheless, although they rarely claimed any economic gain from the pearl fisheries, they continued to petition for pearl-fishing licenses.

The contradictory reports that the Spanish
Crown received concerning this mysterious peninsula caused King Carlos II to launch an official expedition in the late 17th century (from 1683 to 1685) to evaluate California's economic potential, in order to help the colonial administration decide whether it should establish a settlement there. After an intensive six-month survey, during which the Indians were forced to extract even the youngest oysters, Admiral Atondo y Antillón recovered only some misshapen pearls of very little value. He reported an alarming impoverishment of the pearl-oyster grounds (Californiana III). This early overexploitation of the pearl-oyster populations can be considered Baja California's first ecological disaster.

Given these poor prospects, the Spanish Crown decided to divert its limited resources to other regions, with greater economic potential, leaving administration of the area largely to the Catholic church. Since the beginning of Jesuit colonization in 1697, the missionaries' domain had expanded from the spiritual to the material, thus 
giving them the power to restrict pearl fishing. As a result, between 1697 and 1740, the pearl-oyster grounds were largely replenished by natural recruitment.

In 1740 , a bizarre natural occurrence resulted in the expulsion of thousands of pearl oysters from the ocean onto the northern shores of the Gulf. This rare occurrence (in fact, this is the only one known of such a phenomenon) not only changed the Jesuits' plans to keep California free from all kinds of luxury and vain desires, but it altered the history of the entire peninsula as well. The Indians of the San Ignacio mission told a soldier, Manuel de Ocio, of this spectacular event. Ocio then resigned his military post, collected these treasures from the beaches, and began to sell pearls on the mainland. There he bought all the equipment necessary to exploit the virgin pearl-oyster grounds of the northern Gulf of California (del Barco, 1973). From recent investigations, we have concluded that Manuel de Ocio must have collected the rainbow mabe Pteria sterna in particular, since this is the only pearl-oyster species that appears in those northern waters (Monteforte and Cariño, 1992). Although this species produces a pearl that is typically smaller and inferior in quality to that of the mother-of-pearl oyster Pinctada mazatlanica, it has a higher pearl production ratio: Today, approximately $2 \%-4 \%$ of the Pteria Sterna recovered con- tain pearls, as compared to less than $0.3 \%$ for $P$. mazatlanica, according to interviews with fishermen and personal observations from culturing experiments.

Ocio's success marked the first time in Baja California history that riches obtained by exploiting area resources significantly improved local socioeconomic conditions. After intensively fishing the rainbow mabe pearl-oyster grounds for seven years, in 1748 Ocio used his profits to establish mining activities and raise cattle in the southern peninsula (Amao, 1981). Ocio also understood the importance of controlling navigation in the gulf, over which he obtained considerable influence when he obtained exclusive pearl-fishing licenses in both 1754 and 1759 (Gerhard, 1956). The diverse activities he supported contributed to the establishment of a permanent secular settlement and an economic structure that remained almost unchanged until the early part of the 20th century.

It has been reported that, for a period, the number of pearl oysters Ocio's divers captured was so great, no time was spent opening them; instead, they were thrown on the sand to be opened by the heat of the sun (Crosby, 1982). By 1756, however, production was dwindling, as the overexploited pearl-oyster grounds showed signs of severe impoverishment.

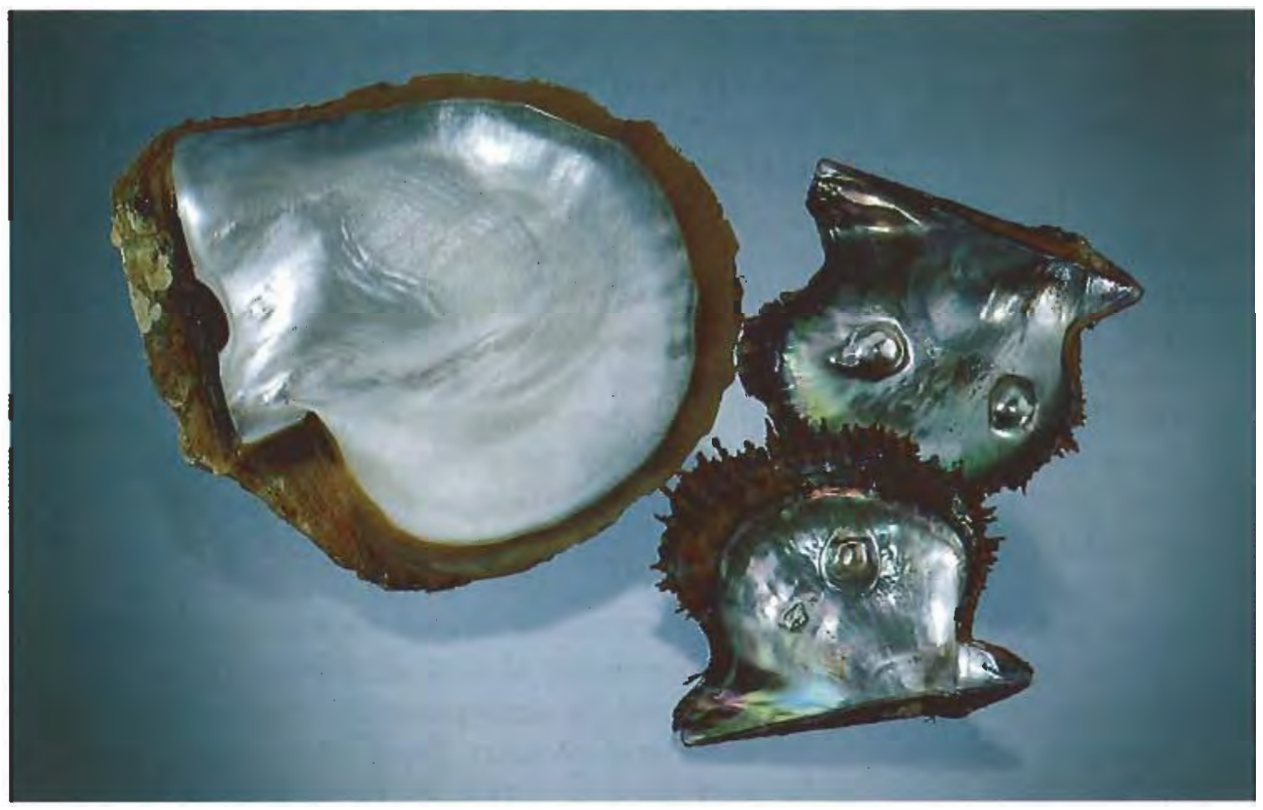

Figure 5. The mother-ofpearl Pinctada mazatlani$\mathrm{ca}(\mathrm{left})$ is the larger and rounder of the two pearl oyster species native to the Gulf of California. The other oyster, Pteria sterna, is smaller and has a unique "wing" projection on the ventral area of the shell. All of these shells came from cultivated oysters. The base of each is about $9.5 \mathrm{~cm}$ wide; the Pinctada mazatlanica is $16 \mathrm{~cm}$ high. Photo (C) Harold et) Erica Van Pelt. 


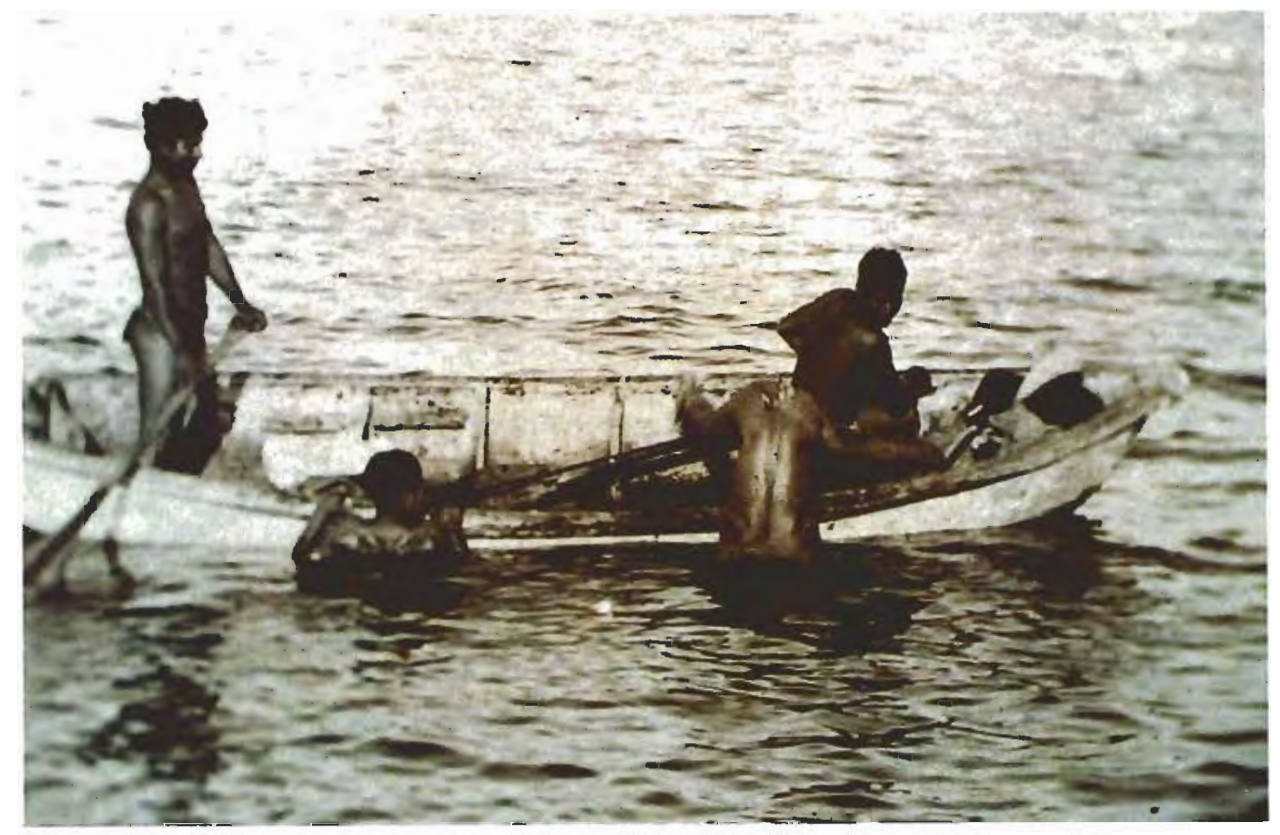

Figure 6. Historically, the most common method of harvesting the pearl-bearing oysters was to dive head-first off a small boat and swim down to the oyster beds. This photo was taken in La Paz Bay around 1908.

Only ignorance of the true condition of the pearl-oyster colonies could explain the enduring faith in the revival of the pearl-fishing industry during the last decades of the 18th century. The Marquis José de Gálvez, Visitador General of New Spain from 1765 to 1771 , tried to create a company with the dual purpose of promoting mining in Sonora and Sinaloa and reestablishing pearl fisheries in the gulf (Navarro, 1964); but despite the involvement of high colonial officialdom, the company only existed on paper. During the late 18th and early 19th centuries, pearl fishing was sporadic. It had become an essentially worthless enterprise due to the deplorable condition of the pearloyster grounds that could be reached by the conventional diving method.

After the Revolution for Independence: A Revolution in the Pearl Industry. When it won political independence from Spain in 1821, Mexico also achieved its independence from Spain's monopoly on commercial activities. This coincided with the natural replenishment of the wild pearl-oyster population that resulted from decades of little to no pearl fishing following the 18th-century exhaustion of the resource.

These were the two main factors that eventually led to a revival of the pearl-oyster industry in Baja California, as foreign investors were attracted by the new Mexican political situation and the renewal of the pearl-oyster beds. Baja California pearls and mother-of-pearl shells again entered the world market, this time with more interesting prospects.

In 1836, a French businessman named Jacques Combier perceived great opportunities in shell exportation (Diguet, 1895), an alternative that the Spaniards had neglected. The nacre of Pinctada mazatlanica, in particular, with its fine orient and iridescence, promptly conquered the European markets and led to the establishment of joint ventures between wealthy local businessmen and European companies dedicated to the export of this valuable product, which was popular for buttons, luxury furniture, fine ornaments and jewelry, inlays in wood and metal, and a variety of handicraft (figure 7).

From 1840 on, export of pearl-oyster shells increased steadily. In fact, the shells became a more important income source than the pearls themselves. The entrepreneurs were able to capture as many oysters as they liked, and use virtually all that they captured, income no longer being determined by the capricious find of a pearl. Yet sales of the pearls that were occasionally found inside the oysters resulted in net profits for the entrepreneurs.

It is important to note that in the first half of the 19th century, almost all the pearl-fishing fleets were owned by entrepreneurs from coastal states on mainland Mexico. From 1850 on, however, it became more common for these fleets to belong to 
residents of La Paz, Mulegé, and Loreto-all cities of Baja California itself (Baja California Archives 2). Most of the divers were Yaqui and Mayo Indians who lived in Sonora and Sinaloa, but from 1851 on, they began moving to La Paz. This migration was a direct result of a proclamation by the Territorial Assembly of Deputies of Baja California, which imposed higher duties on the armadores /those responsible for the administration of the fleets) for divers who did not reside in the territory (Baja California Archives 3).

Largely as a result of these developments, La Paz began a period of prosperity that lasted from the mid-19th century into the 1920s: 75 years that are considered the height of pearl fishing in the Gulf of California. Numerous pearl-fishing fleets explored the waters off La Paz, each employing about 50 divers that still used the same nalked-diving method as during Colonial times. Each fleet was usually composed of one or two brigantines (two-masted sailing ships that served as "mother boats") and several canoes (figure 8). Diving activity was restricted by water temperature and visibility, both of which were best between May and October.

Before the mollusks were opened, they were divided between the armador and the divers in a proportion agreed on at the beginning of the diving season. The only payment the divers received were the pearls found in their share; the armador kept all the shells-and the pearls in his share. The divers were free to sell their pearls to anyone, but they usually gave them to the armador in payment for the food he provided throughout the season (Esteva, 1857).

In 1857, José María Esteva, provisional governor of Baja California, took one of the first measures to conserve pearl resources. He promulgated an ordinance that established four fishing zones in the Gulf of California, but authorized pearl fishing in only one of them annually, thus giving the other three time to recover their natural stocks. Local judges were to oversee the efficient implementation of these measures and designate sites where divers were required to plant adult oysters to help natural repopulation of the pearl-oyster beds. Unfortunately, the lack of funds to enforce these ordinances rendered them ineffective, and overexploitation again ensued. By 1870, the pearl-oyster populations established from 2 to $25 \mathrm{~m}$ depththat is, those that could be harvested by the traditional diving method-were, once again, almost completely exhausted. Only the introduction of compressed-air diving suits enabled the pearl fisheries to continue operating, since this equipment allowed the exploitation of deeper areas (Mosk, 1941).

\section{NEW TECHNOLOGY BROADENS PEARL FISHING: INTRODUCTION OF THE DIVING SUIT}

Beginning in the early 19 th century, there were several failed attempts to introduce modern diving techniques in the region. Compressed-air diving gear (called "scaphanders" at the time; figure 9) was not successfully used in this region until 1874, when two divers, an Italian and an American, arrived in La Paz with eight sets of gear they had previously used for pearl fishing in the Gulf of Panama (Diguet, 1895). By exploiting the untouched pearl-fishing grounds located below 30 $\mathrm{m}$, they gained a fortune so great that they retired after only six months, having paved the way for the modern era of pearl exploitation in Baja California. Local pearl entrepreneurs with sufficient financial resources immediately began importing similar equipment from Europe and the United States.

Figure 7. During the 19 th and early 20 th centuries, the shells (for their mother-of-pearl)-and not just pearls-became an important export for Baja California. Earrings such as these (5.5-6.5 $\mathrm{cm}$ long) represent just one of the great many uses of mother-of-pearl. Photo (C Harold es Erica Van Pelt.

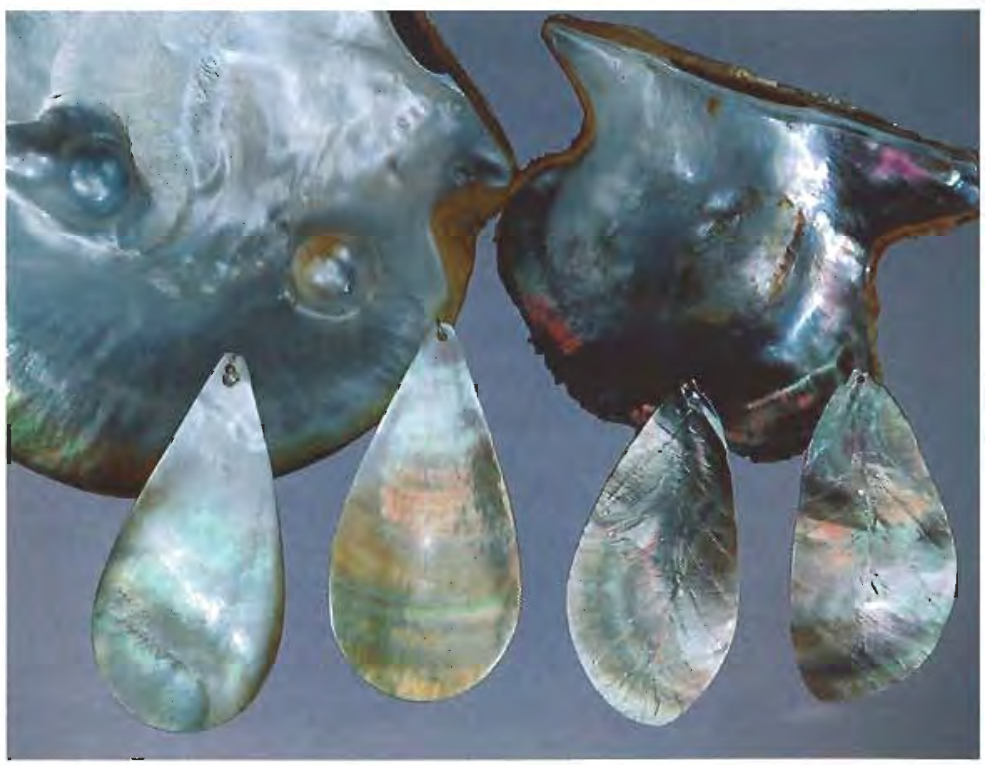




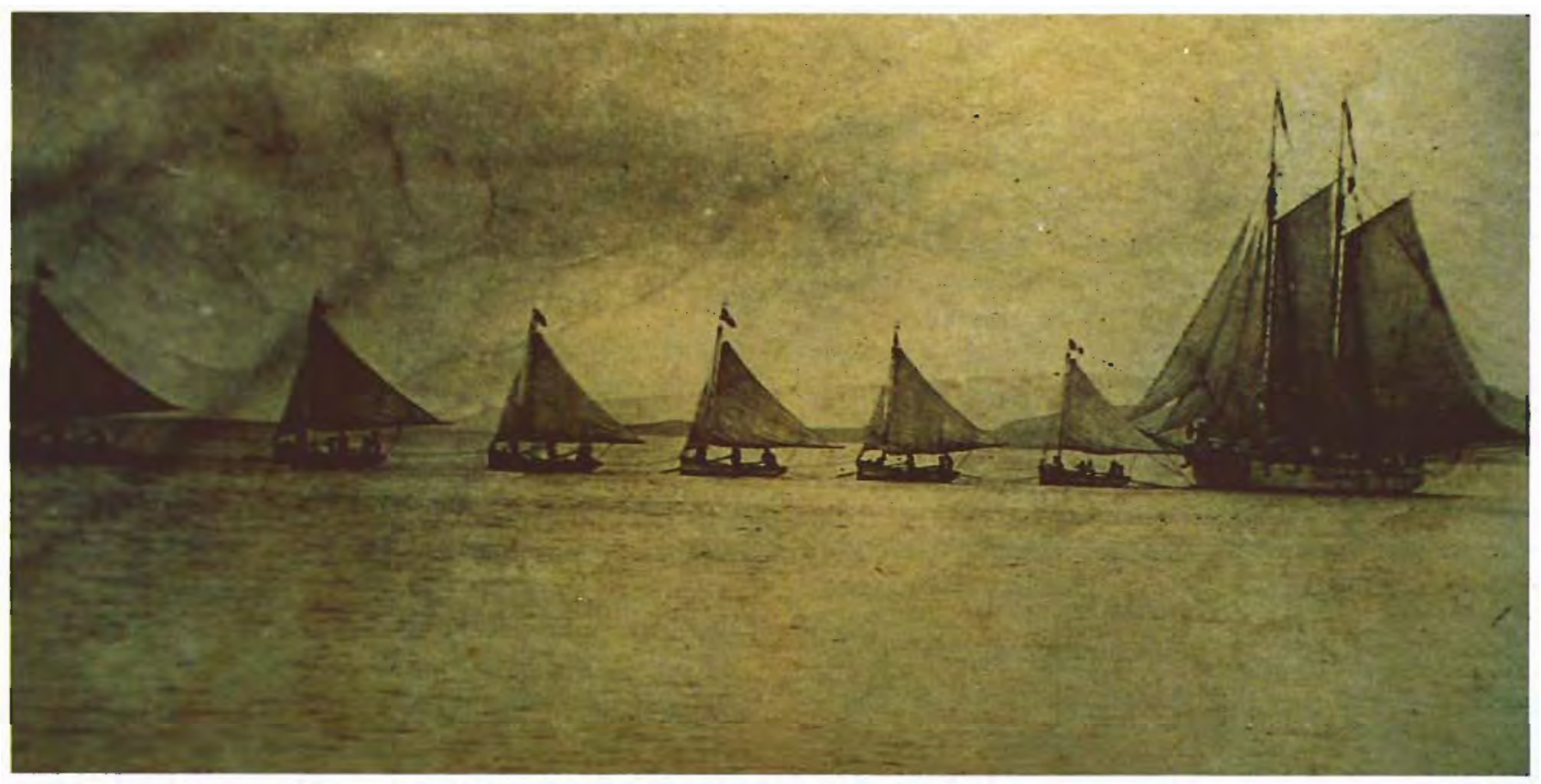

Figure 8. Pearl-fishing fleets, like the one in this 1914 photo, were a common sight off La Paz from the mid19 th century into the 1920s, the height of Baja California pearl fishing. The fleets usually consisted of one or two "mother boat" brigantines and several canoes.

The use of diving suits not only increased both attainable depth and immersion time /divers were able to descend as deep as 70-80 $\mathrm{m}$ and work there for more than two hours at a time, although there were many fatal decompression accidents), but it also extended the diving season, since the temperature of the water and visibility were no longer obstacles. As the equipment became more sophisticated, however, costs also increased, thus limiting opportunities for involvement in the industry to relatively wealthy businessmen and important companies owned by foreign and national investors.

Between 1884 and 1912, President Porfirio Díaz endowed virtually exclusive pearl-fishing rights to five foreign companies. One of the most important was the Compañia Perlifera de Baja California (the Pearl Company of Baja California), which collected pearl oysters throughout almost all the Mexican Pacific coastal region (Mosk, 1941). According to observations made in 1889 by naturalist Charles $\mathrm{H}$. Townsend, the Compañia Perlifera employed between 400 and 500 men every year and owned about 70 diving units (Townsend, 1889). During the summer, the company worked the pearl-oyster grounds off the Gulf of California coast; in the autumn, it worked those lying off the continent. Huge quantities of shells were kept in its three large La Paz warehouses, ready to be shipped to European markets, where they would be used for the manufacture of various mother-of-pearl items. In 1889, eight tons were exported. Most of the pearls were sold in Paris and London. Prices for both products were as much as 60 times higher on the international market than locally, assuring large profits for concessionaires (Kunz and Stevenson, 1908).

In exchange for granting exclusive fishing rights, the government imposed various conditions, such as the employment of Mexican workers, the nontransferability of concessions without specific authorization, a prohibition on fishing young oysters, payment of a tax per ton of shell to the maritime customs, and an obligation to start experiments on cultivation. The first two conditions were easily accomplished by almost all the companies, since local labor was very cheap and no company was willing to give up its concession; the following two were scarcely practiced; and the last condition was observed by only one company, as will be discussed later.

In 1893, the Compañia Perlifera sold its entire concession to the Mangara Exploration Company, which had been originally created with British capital (Mosk, 1941). In the Gulf of California, the Mangara concession included the eastern coast of the peninsula from the mouth of the Colorado River to Cabo San Lucas (extending from the shore 
to $10 \mathrm{~km}$ seaward), and on the continental Pacific Coast, from the port of Mazatlán south to the border with Guatemala (extending $5.5 \mathrm{~km}$ seaward), including the territorial waters of the Marias Islands (Baja California Archives 4; again, see figure 4). However, the concession near La Paz Bayincluding the islands of San José, Espíritu Santo, and Cerralvo-remained under the control of local Mexican entrepreneurs.

Mangara Exploration had considerable success, annually collecting between 175 and 200 tons of shells. Despite the enormous profits, however, it paid low salaries and imposed difficult working conditions (Baja California Archives 4). From an ecological perspective, the excessive exploitation of all marine resources, pearl oysters in particular, had once again depleted the natural oyster population. Mangara routinely used explosives, extracted immature oysters, and destroyed the sea grounds without fear of reprisal, due to the lack of government vigilance. Moreover, the large concession held by this company eliminated many opportunities for Mexican fishermen and pearl entrepreneurs lat this time, unsanctioned diving was sternly punished as an unlawful activity|. This situation led the people of South Baja California to demand revocation of the Mangara contract and liberation of the pearl fisheries (Baja California Archives 4). In 1912, following the first movement of the 1910-1921 Mexican Revolution, President Francisco Madero rescinded the contract /which was supposed to last until 1932) and indemnified the company with the then-huge sum of 300,000 pesos.

\section{DEVELOPMENT OF PEARL OYSTER CULTIVATION IN BAJA CALIFORNIA}

The damage done by Mangara magnified the importance of repopulating the pearl grounds through artificial breeding. This was accomplished on Espíritu Santo Island by Gastón J. Vives in the early part of the century. Only these efforts prevented this resource from being totally depleted by that time.

The Role of Gastón Vives. In 1880, Gastón Vives (1859-1939) was sent from Baja California to France to study medicine. However, his interests turned toward biochemistry, particularly the cultivation of flat oysters. After familiarizing himself with artificial breeding procedures, he decided to try applying them to pearl oysters.
Following his return to Baja California by 1885, Vives held important positions in the local municipal government (he was La Paz's first town councillor from 1894 to 1911; Baja California Archives 5). His political influence worked to his advantage, as he was granted the concession for pearl-oyster fishing in nine lagoons and along one island off the coast of La Paz Bay (Baja California Archives 6). The experience he gained from his early pearl-fishing ventures provided knowledge in the management of diving fleets, the world market for pearls and nacre, and the history of overexploitation in the local pearl fisheries. All of this served to his advantage when, in 1903, he founded the Compañia Criadora de Concha y Perla de Baja California (CCCP).

Meanwhile, in 1893, A. P. Cattet sent a report to the governor of South Baja California in which

Figure 9. With the introduction of compressed-air diving gear in the late 19th century, the divers were able to go far deeper in the water and stay for a much longer period of time, thus greatly extending the range of pearl-oyster beds that were accessible. Helmet and safety rope in place, a diver working for Compañía Criadora de Concha y Perla goes over the side of a "mother boat" off La Paz. Photo circa 1912.

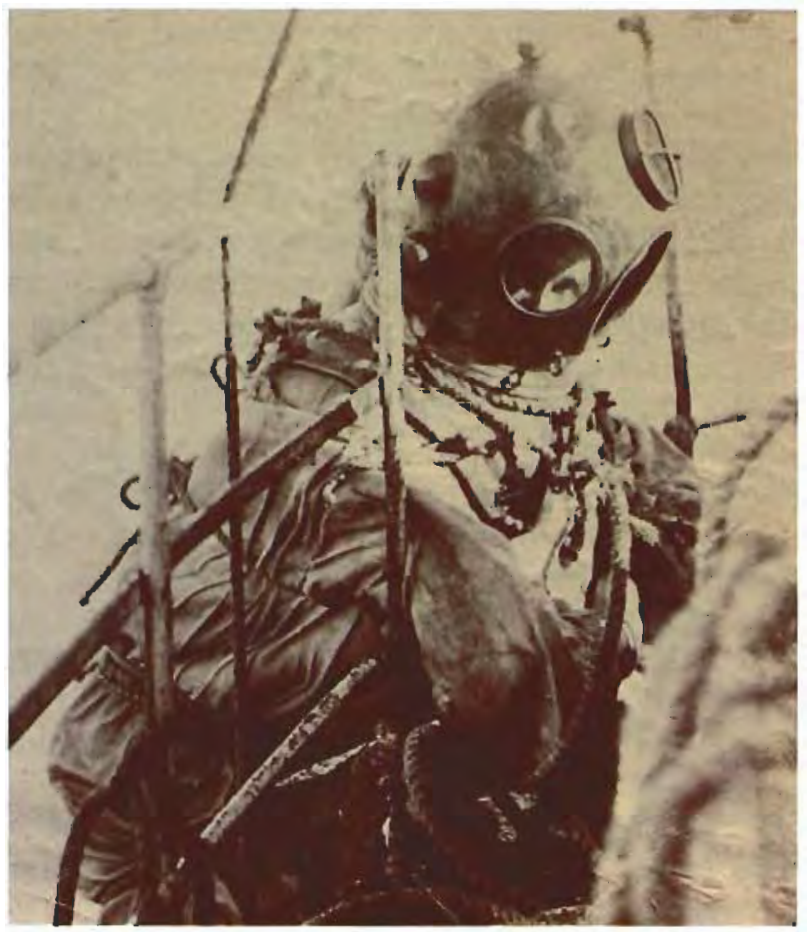




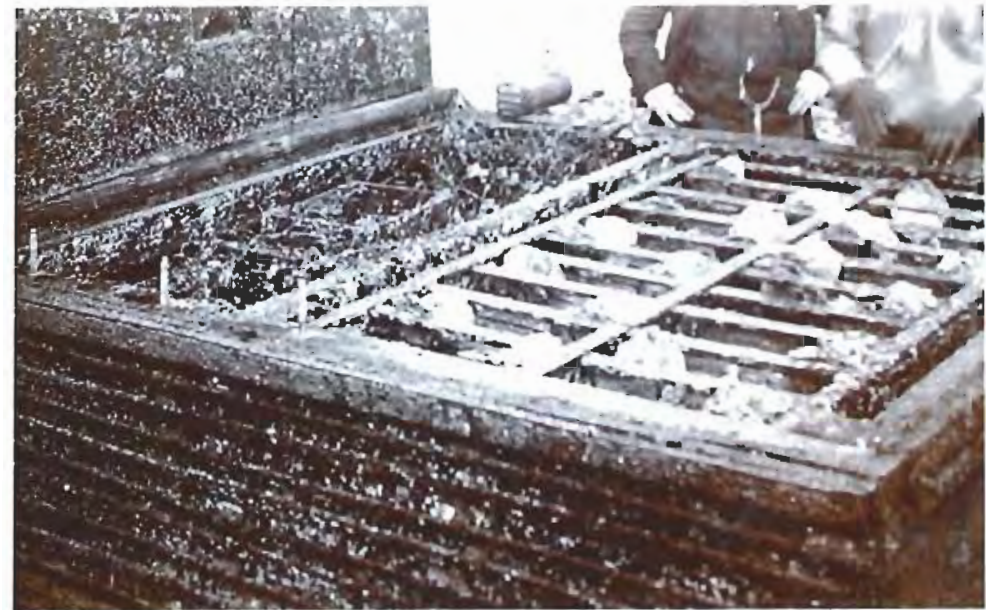

Figure 10. Open for inspection in this undated photo is one of several hundred "incubators," or spat collection devices, used by Gastón Vives in the Compania Criadora de Concha y Perla. The 9$m^{3}$ wooden boxes were covered by 1-cm-mesh galvanized wire that permilted proper water circulation but excluded oyster-hungly predators.

he described pearl-oyster cultivation techniques in "Oceanie" (the lands of the central and South Pacific, including Polynesia). After first warning that his specifications might not be valid for different sites or species, Cattct proceeded to explain the specific requirements for the successful artificial breeding of pearl oysters (Baja California Archives 7). He stated that the cultivation structures are best placed at a depth between 10 and $12 \mathrm{~m}$ in locations where the water currents do not exceed one knot. He also noted the advantage of coraline and rocky bottoms, as well as the benefits of shade, for the growth and survival of pearl oysters. Cattet's strategy for spat collection involved deploying collectors near dense pearl oyster beds and stressed the need to survey the collectors monthly. He also emphasized that the juveniles must remain in the collectors until they reached at least 4 or $5 \mathrm{~cm}$ in diameter (if we assume that Cattet was referring to the French Polynesian Pinctada margaritifera, this size would correspond to an age of approximately 2.5 to 3 months), and indicated their proper spacing and extension in the nurseries. We believe that this document establishes that the world's first positive pearl-oyster cultivation results wcre obtained in the islands of the Tuamotu Archipclago, in French Polynesia.
Vives / who, because of his position and his knowledge of the French language, may have read or even translated Cattet's report) nevertheless holds the distinction of having been the first to integrate such techniques into the large-scale cultivation of pearl oysters, in this case Pinctada mazatlanica (Cariño, 1994; Cariño and Cáceres, 19901, which was preferred over Pteria stema because of the larger size of its shell and its superior mother-of-pearl (again, sec figure 5). The outstanding scientific work of Vives was recognized by several American and European naturalists, including Leon Diguet (1919) and Charles Townsend (1911), both of whom visited the CCCP when it was active.

Technological and Commercial Aspects. For the CCCP, Vives designed original and efficient devices to function in cach of the three phases of cultivation: spat collection, nurscry cultivation, and late cultivation. He also built an impressive infrastructure at San Gabriel Inlet on Espíritu Santo Island in La Paz Bay, creating the first pearling station in the world, of which only a fow ruins remain today.

For spat collection, Vives manufactured 9- $\mathrm{m}^{3}$ wooden boxes with compartments of 1-cm-mesh galvanized wire (figure 10). This permitted proper water circulation and prevented the entrance of predators. Inside these "incubators," he placed old shells and branches of a local water-resistant bush |chivatol, as well as live mother-of-pearl oysters that were intended to serve as sources of larvace and spat (Vives, 1917-1919). Several hundred of these boxes were submerged in La Paz Bay at sites selected by Gaston Vives based on their oricntation and exposure to water currents.

The incubators remained under water from May to October, the reproductive season of Pinctada mazatlanica (Monteforte and GarcíaGasca, 1994; Monteforte and Bervera, 1994). Vives claimed that spawning and fertilization took place inside the incubators, and that the spat would settle on the substrates provided. However, it is highly unlikely that this is entirely accurate given the reproduction process for mollusks (Alagarswami, 1970; Monteforte and García-Gasca, 19941.1 Nevertheless, the average spat yield was about 10,000 individuals per box.

At the end of the collocting season, the heavy incubators were transported from the collection 


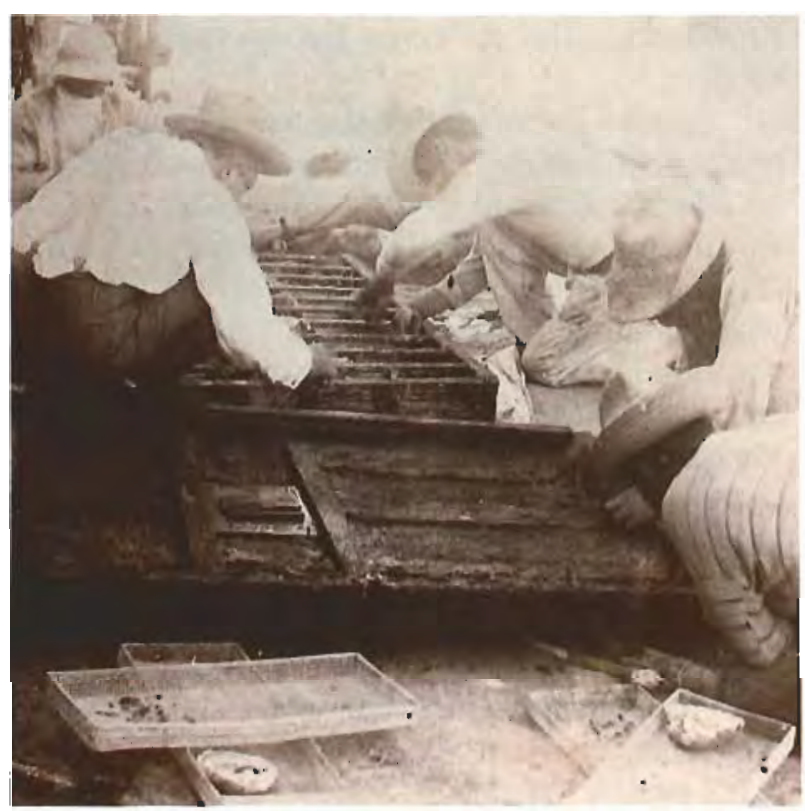

Figure 11. CCCP workers carefully harvest young pearl oysters by hand from an "incubator." Average spat yield was about 10,000 per box.

sites to the pearling station at San Gabriel, where they wcre pulled ashore onto a concrete platform. There, under a large shed, the CCCP workers harvested the several million young oysters by hand (figure 11). They then transferred them to wire cages that were placed into special channels built at San Gabriel Bay, where the oysters remained during the nursery cultivation stage.

The San Gabriel nursery station was the most outstanding of Gastón Vives's inventions. He made

${ }_{1}^{1}$ Fertilization in mollusks takes place in water when male and female gametes are released en masse by the individuals. It is a very hazardous process in which only a few ova will successfully meet the corresponding spermatozoid. (Of the almost 40 million gametes released by these species during spawning, only a few individuals will actually reach full size.) After fertilization, the mollusks pass through several microscopic larval stages until, at the final stage (called Pediveliger), the larvae begin to seek an appropriate substrate on which to settle. Once setcled, the Pediveliger metamorphoses into a tiny spat (about $1 \mathrm{~mm}$ or smaller), with the shape of an adult, and begins to grow. This process, which takes place completely under water, lasts about 25 days in pearl oysters, during which time the larvae move freely with the currents. It is, therefore, not very probable that all of the larvae stayed in the incubators -constrained only by a 1-cm-diameter mesh-for the 25 to 30 days Vives indicated. Because of their concentration of adult mollusks, however, incubators do offer a higher probability of contact. good use of the hay's coastal topography to build a dikc $500 \mathrm{~m}$ long and $10 \mathrm{~m}$ wide, which transformed the inlet into a lagoon. Communication between the bay and the lagoon was achieved by means of a complex network of 36 channcls and dams using tidal cycles (figurc 12). The young pearl oysters (2-3 months old, $1-2 \mathrm{~cm}$ in dianeter) harvested from the incubators were placed in these channcls at a depth of 1.5 to $2.5 \mathrm{~m}$. The oystcrs were installed in individual compartments in wire cages $(1 \times 0.3 \mathrm{~m}$; figure 13$)$ on the bottom of the channels, where they remained for six to eight months (the nurscry cultivation stage) until they attained a diameter of about $6 \mathrm{~cm}$. The channels were covered hy palm sheds which eliminated excessive illumination and heat, but allowed sufficient air circulation to kecp the water fresh during the hot season. Channel entrances were protected by fences that prevented the incursion of predators crabs, lobsters, octopus, borer and carnivorous snails, rays and other large fish, etc.); in addition, guards armed with harpoons were posted at channel entrances and exits to kill any predator that succeeded in passing through the gate.

Figure 12. Palm-frond-covered roofs protect young oysters from too much heat and sun in a section of Gastón Vives's most outstanding invention- the San Gabriel Inlet nursery station. After harvest from the incubators, young pearl oysters were placed here in a complex of 36 channels and dams that harnessed tidal cycles. Fences and harpoon-wielding guards prevented crabs, lobsters, octopus, and other sea-dwelling predators from entering the nursery.

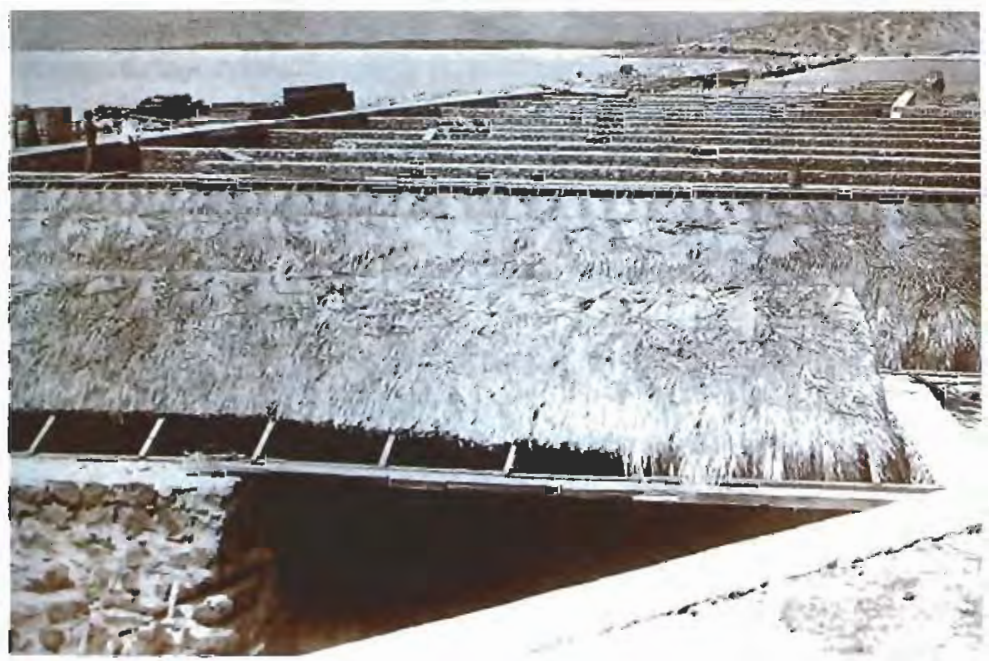




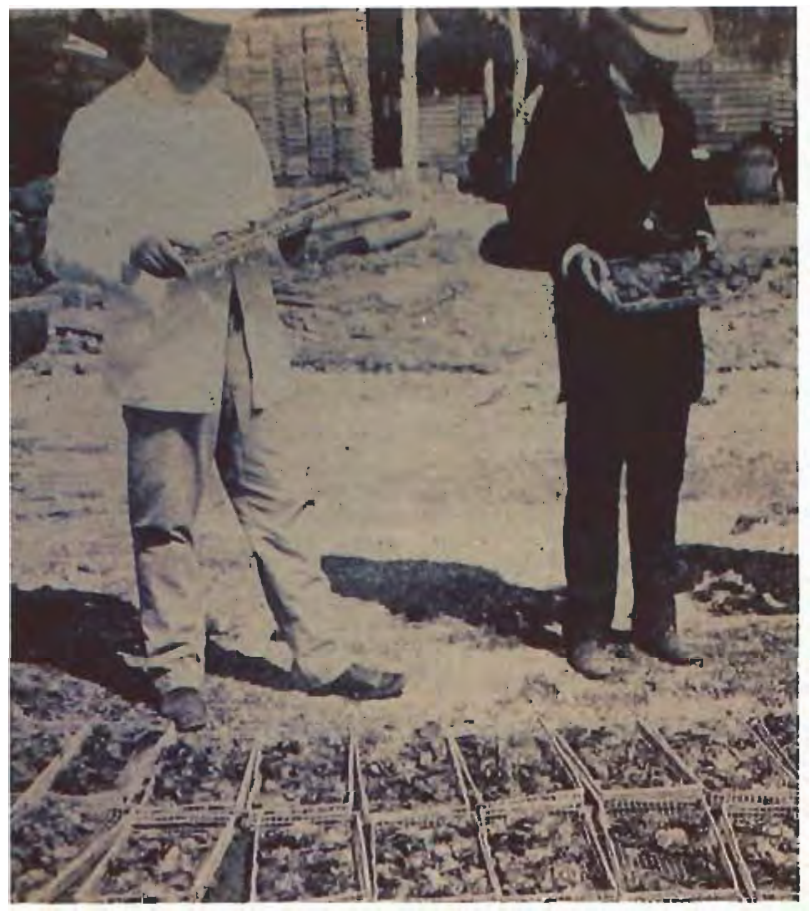

Figure 13. Gastón Vives (right) and his associale, Antonio Ruffo, examine wire cages filled with young pearl oysters ready for the San Gabriel Inlet nursery station.

When the oysters reached around $6 \mathrm{~cm}$, they were taken from the nurseries and returned to the sea for the third and final cultivation stage. Vives used different methods to promote the growth and survival of these oysters and the formation of natural pearls. One innovation was the creation of several hectares of artificial rocky grounds in inlets and creeks chosen for their appropriate ecological characteristics and their high incidence of natural pearls. For these special grounds, Vives used canoes to transport huge boulders from the coastal hills. In addition, he further protected potential pearl-bearing oysters by shielding them with wire mesh and encasing them in individual handmade "suits of armor" with floating cork rudders (figure 14).

After three years, the oysters $(16-18 \mathrm{~cm}$ in diameter, sometimes larger) were collected by CCCP divers (see, e.g., figure 9) and inspected for pearls in the fishing-fleet "mother boat," under strict supervision (figure 15). During the period 1909 to 1914 , there were up to four harvests per year, yielding a total annual production of 5 million shells (10 million valves; 900 tons) for export, and between 200,000 and 500,000 natural pearls of superior quality (J. Vives Lucero, pers. comm., 1987).

To give some idea of the significance of this production and the randomness with which natural pearls are found in the Gulf of California, we should mention that Manuel de Ocio obtained about $265 \mathrm{~kg}$ of pearls between 1740 and 1747, whereas some 55+ years before, Admiral Atondo y Antillón had found virtually nothing. It is estimated that, because of the sites selected and the techniques used, on average approximately $8 \%-10 \%$ of the CCCP-cultivated oysters produced pearls, one of the highest percentages of any known pearling area (Vives, 1908). Toulemont (1992, p. iv) states that "to find a fine natural pearl, it was necessary to open 500 oysters in the Persian Gulf, 5,000 in the Philippines Archipelago, and 15,000 Pinctada margaritifera were necessary to find a bcautiful black pearl in French Polynesia. In Ceylon, nearly one million oysters were needed to get some dozens of pearls..."

CCCP shells and pearls entered the world market in a relatively straightforward fashion. The mother-of-pearl shells were shipped to European and American markets in large wooden boxes. Gastón Vives personally traveled once or twice a year to New York and Paris to sell his pearls to the most important jewelers (J. Vives Lucero, pers. comm., 1987).

Aside from Vives's business and scientific expertise, it was the excellent reputation of Baja California pearls and nacre (again, see figures 2, 3, and 5) on the international market that was the most important element in the $\mathrm{CCCP}^{\prime}$ s rapid growth. At that point in history, both products fed a vigorous industry in Europe and the United States (Coeroli, 1994): The first two decades of the 20th century were the last years before artificial materials, such as plastic and acrylic, replaced natural (mother-of-pearl) nacre and before culturcd pearls appeared on the world market (Taburiaux, 1983; Levi and Poirot, 1992).

Other Early Pearl Oyster Cultivation Efforts. In the 1890 s and early 20th century, other pearl-oyster cultivation operations were set up, contemporaneous to the CCCP. As we mentioned earlier, these efforts started in French Polynesia with cultivation of the Pinctada margaritifera cumingi. Although these were the most advanced operations of the day, the methods involved only rudimentary spat collection using stones and tree branches. Also at 


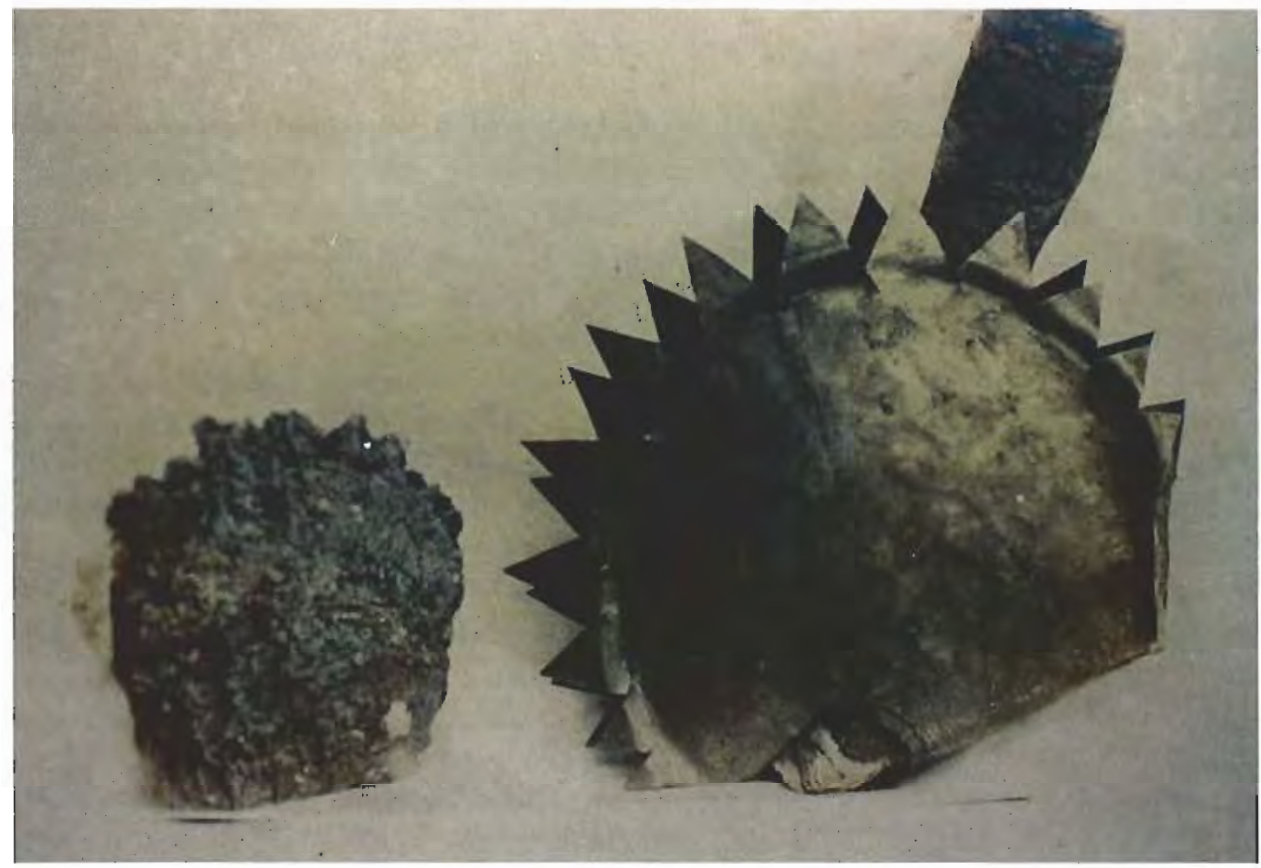

Figure 14. Before being returned to the sea for the third and final cultivation stage, each pearl oyster (like the one at left) was individually protected to discourage natural predators. Some were encased in wire mesh; others-like the one here-were outfitted with handmade spiked "suits of armor." The cork rudders (top right) provided orientation for the oysters as they were deposited on the sea bottom at the culturing sites.

this time in French Polynesia, laws were enacted banning pearl-oyster fishing during the oysters' reproductive season and setting aside a portion of the atolls (and also into the atolls) to create reservation areas (Bouchon-Brandeley, 1885). However, neither the scientific research nor the conservationist measures were enough to avoid the continued impoverishment of these resources in the Tuamotu atolls (Ranson, 1955) until the 1960s, when extensive pearl-oyster cultivation and pearl culturing operations were successfully introduced (Coeroli, 1994).

In Ceylon's Gulf of Mannar, also at the end of the 19th century, several measures were taken to facilitate spat settlement and natural repopulation of the Pinctada fucata beds (Hornell, 1905). However, these early measures, which could be considered precursors of pearl-oyster cultivation, did not give the expected results. Eventually, the ephemeral spawning season of the species and the constant overexploitation combined to destroy the oyster beds (Jameson, 1912).

Among the rare successful ventures of the period, in addition to that of Gastón Vives, only those of Cyril Crossland (from 1905 to 1923) and Kokishi Mikimoto (which began in 1890) are noteworthy.

Cyril Crossland headed the world's second most successful large-scale pearl-oyster-cultivation operation, at Dongonab Bay in the Red Sea (Crosslan, 1931, 1956). Employed by the Sudanese government for this purpose, Crossland made sub- stantial advances in the cultivation of Pinctada margaritifera (spat collection, nursery cultivation, and late cultivation). Each stage required the design and refinement of several devices and strategies for

Figure 15. Under the ever-watchful eyes of CCCP supervisors (right), workers on a "mother boat" search for pearls in iust-harvested, three-year-old cultivated oysters (about $16-18 \mathrm{~cm}$ at their longest dimension).

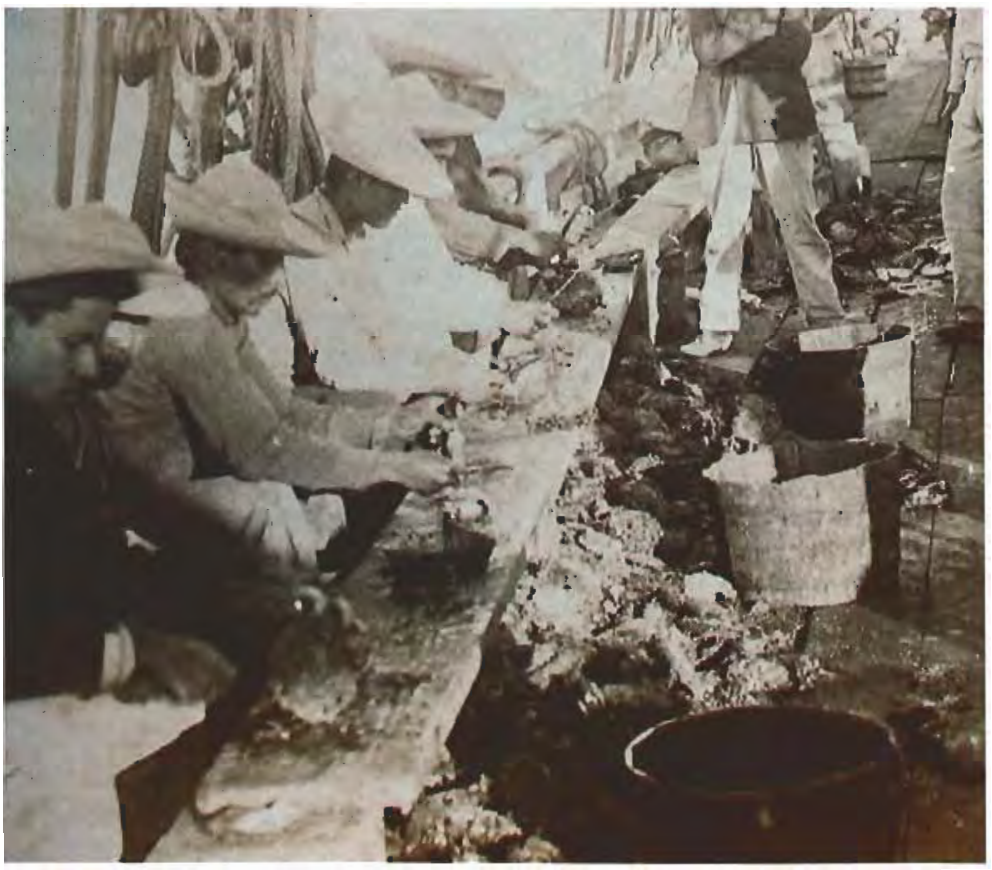


their installation. In 1911-1912, he shifted from an experimental level to a large-scale commercial enterprise, obtaining a harvest of 3 million spats. Between 1914 and 1920, World War I disrupted production; but in 1920, with more scientific knowledge and better technology, Crossland harvested more than 4 million spats, which resulted in 1.7 million commercial-size pearl oysters. In 1921, he collected a record 9 million spats, recovering 4.5 million oysters at the nursery cultivation stage. At the height of activity, Crossland employed as many as 300 persons. (Unfortunately, we know of no published record of the number of pearls produced.) In 1923, however, the Sudanese government canceled Crossland's contract because of decreasing prices for mother-of-pearl shell in the international markets. Within a few years, the pearl-oyster fisheries in the Red Sea-no longer replenished by Crossland's "breeding center" were severely impoverished.

Cyril Crossland's work, because of its complex technology, is the only one comparable to that of Gastón Vives. However, large-scale pearl-oyster cultivation in Dongonab Bay started 10 years after the CCCP.

Kokishi Mikimoto's operation could also be considered a highly successful experience in the cultivation of pearl oysters. Having started in 1890 , by 1896 Mikimoto had made his first commercial harvest of cultured blister pearls in the market (Jameson, 1914). Nevertheless, his pearl-oyster cultivation techniques were as rudimentary as those employed at the time in French Polynesia: the simple deposition of rocks on the sea bottom of some protected areas to provide substrates on which the pearl-oyster spat (Pinctada martensii) could settle. During this period, he did not have any farms comparable in size to that of the CCCP. Mikimoto's success depended primarily on having the appropriate environmental conditions and the excellent response of Pinctada martensii to aquaculture management. The successes at Dongonab and La $\mathrm{Paz}$ Bays were the result of extensive experimentation and the refinement of methods and equipment to control the environments in which the pearl oysters grew. Although cultured pearls were competitive with natural pearls by the 1920 s, Vives never proposed producing the former during his attempts to re-establish the San Gabriel pearling station; he preferred not to alter the processes of natural pearl formation (Vives, 1918). While Mikimoto was clearly the pioneer in pearl culturing, Vives led the way in pearl-oyster cultivation.
Socioeconomic and Ecological Impact of the CCCP. In only 11 years (1903-1914), Vives created an internationally recognized pearl-oyster breeding empire. The CCCP also had a significant impact on the local socioeconomic structure, as well as on the regional marine ecology.

During its most productive years (1909-1914), the CCCP employed between 400 and 500 workers (Cariño and Cáceres, 1990; Cariño, 1994|, representing almost $6 \%$ of the registered population of La Paz (which was about 8,647 in 1910; Baja California Archives 8). Most of these workers were based at the San Gabriel pearling station and were involved in the cultivation process itself or in such activities as manufacturing cultivation devices, piercing and transporting stones, and the like. Sailors, divers, and other fleet support personnel were also part of the CCCP work force. All employees were strictly supervised. Due to the magnitude of its operations (direct or indirect), its accumulation of capital, and the size of its work force, the CCCP was the most important enterprise in the region during the first decades of the 20th century.

Species conservation through continuous replenishment of the natural mother-of-pearl beds was the CCCP's most important ecological contribution (Estrada, 1977). Vives proved that through extensive and large-scale aquaculture, it is possible to rationally manage a pearling resource despite intensive exploitation.

From 1911 on, Vives's political fortunes began to decline. That year, he was the first local administrative official tied to the regime of President Porfirio Díaz who was publicly asked to resign (Baja California Archives 9). The June 1914 arrival in La Paz of a revolutionary detachment commanded by Colonel Miguel L. Cornejo dealt al mortal blow to the CCCP.

Before becoming a revolutionary, Cornejo had also been a pearling entrepreneur, a rival of Vives (Baja California Archives 10), and he did not miss this opportunity to ruin his bitter enemy. All the equipment, pearl oysters, pearls, shells, and any other property of Gastón Vives was confiscated or destroyed. Vives was forced to flee aboard an American steamboat (Vives, 1914). From 1916 on, Vives repeatedly petitioned the federal government to reissue his concession and return his unjustifiably appropriated property so that he might renew his aquacultural activities (Baja California Archives 10). In 1918, and again in 1930, he tried to interest both American and French businessmen in reviv- 


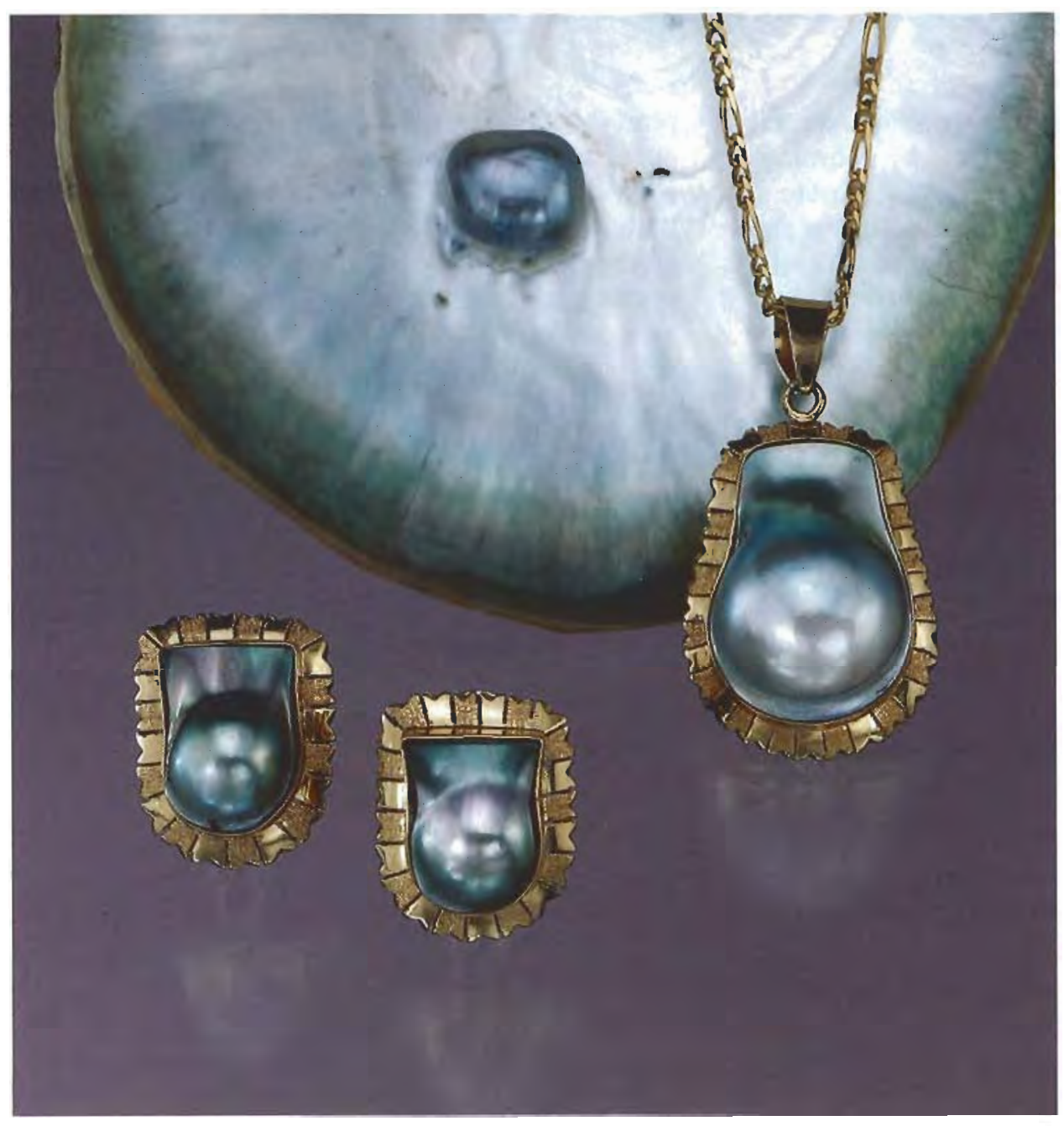

Figure 16. Cultured blister pearls, like those shown here, have been recovered recently from 26-month-old cultivated Pinctada mazatlanica oysters. The cultured pearl in the pendant is about 15 mm in diameter; the two in the earrings are each about $9 \mathrm{~mm}$. Note that the nacre has an average thickness of $2.3 \mathrm{~mm}$. Courtesy of the Pearl Oysters Research Group, CIBNOR; photo $(0)$ Harold ets Erica Van Pelt.

ing the CCCP (Vives, 1918; J. Vives Lucero, pers. comm., 1987), but all his efforts were unsuccessful.

\section{PEARL OYSTER CULTIVATION TODAY: THE LEGACY OF DON GASTON VIVES}

After hundreds of years of arbitrary or poorly managed exploitation of the pearl oyster Pinctada Mazatlanica, the organized farming of these mollusks was finally accomplished in the early 20th century - and destroyed within a few short years. As Cattet stated in his 1893 report, and contemporary scientists and pearl-oyster cultivation technicians have confirmed (see, e.g., Monteforte, 1990), the transfer of aquaculture procedures from one species to another does not assure success, as it is necessary to adapt many details of each procedure to the specific species and to local biotic and abiotic characteristics. Since Gastón Vives's delineation of these essential conditions for La Paz Bay, there have been many failed attempts to reinstate mother-of-pearl farming and pearl culturing in Baja California. However, the recently established Pearl
Oyster Research Group of the Northwestern Center of Biological Research (Grupo Ostras Perleras, Centro de Investigaciones Biológicas del Noroeste-CIBNOR) has succeeded in applying extensive cultivation techniques and repopulation strategies, to accomplish the production of cultured pearls, the first positive results in 90 years (Monteforte and Aldana, 1994; Monteforte and Bervera, 1994; Monteforte and Wright, 1994; Monteforte et al., 1994a and b). We believe that this recent success is due to our focus on the bioecology of the species and their response to different cultivation manipulations-the same factors that Vives had considered critical (Vives, 1908).

The Mexican Government now recognizes that pearl-oyster cultivation and pearl culture are strategic alternatives for regional socioeconomic development. Although the current CIBNOR operation is limited-five researchers managing several experiments with a stock of about 8,000 oysters of different generations-we have already produced some high-quality 12-15 $\mathrm{mm}$ cultured blister pearls 
(figure 16), and we anticipate a harvest of approximately 1,000 cultured blister pearls by FebruaryMarch 1996. From periodic checking of the oysters, we believe that at least $70 \%$ of these will have the rich, distinctive colors of Baja California pearls. Results with round pearls have been much more modest, because of limited facilities. Although the failure of earlier attempts (subsequent to Vives) at pearl-oyster cultivation and pearl culturing has produced much skepticism in Mexico, recent successes in the production of cultured blister pearls from both Pinctada mazatlanica and Pteria sterna have generated renewed interest in establishing a pearling operation in La Paz. We are confident that, once again, Baja California pearls will grace the world market.

\section{REFERENCES}

Alagarswami Q. \{1970\} Pcarl culture in Japan and its lessons for India. In Proceedings of the Symposium of Mollusca, Part III, Marine Biological Association, India, pp. 975-993.

Amao J. (1981) El Establecimiento de la comunidad minera en la California Jesuitica (Establishement of the mining community in Jesuitic California). Colección Cabildo, Serie Premios, La Paz, Mexico, $46 \mathrm{pp}$.

Baja California Archives 1. Documents in the historic archives (Archivo Histórico Pablo L. Martínez) of the State of Baja California Sur, Mexico. Fomento, Mexico 1903, Vol. 365, Exp. s/n (leasing contract of Espíritu Santo Island to Don Gastón Vives).

Baja California Archives 2. Vol. 36, 42, 43, 44, 47, 48 (several lists of divers and fishing fleet owners proving their south Californian origin).

Baja California Archives 3. - Fornento, La Paz 1851, Vol. 47, Docs. 41,329, 323 (decrees of the Territorial Assembly of Deputces of Baja California).

Baja Califomia Archives 4. —_. Fomento, Mexico 1912, Vol. 569, Exp. 147 (lcgal document of the Mangara concession indicating its geographic limits\}

Baja Califomia Archives 5. —- Gobennacion, La Paz 1911, Vol. 553, Exp. 23 /document proving the nomination of Don Gastón Vives as First Town Councilor, 1894-1911).

Baja California Archives 6.--_ Fomento, La Paz 1895, Vol. 254, Exp. 24 (concession to Gástón Vives for nine lagoons and an island.

Baja California Archives 7. - Gobernación, La Paz 1893, Vol. 164, Boletín Oficial del Gobierno del Distrito Sur de la Baia California, No. 37 (publication of the report of A.P. Cattet\}.

Baja California Archives 8. Fomento, La Paz 1911, Vol. 538, Exp. 162 (census of La Paz City).

Baja California Archives 9.-_—. Gobernacion, La Paz 1911, Vol. 553, Exp. 23 (letter sent to Gastón Vives by the pcople of La Paz demanding his resignation as First Town Councillor).

Baia California Archives 10. - Archivo del luzgado de Distrito, Juicios de Amparo, Expedientes: 29/918 and 1/919; and Fomento, Mexico, Enero 1915, Vol. 646, Exp. 6 (several trial transcripts, Gastón Vives vs. Migucl L. Cornejo for robbery and damages!.

del Barco M. (1973) Historia Natural y Crónica de la Antigua California (Natural History and Chronicles of Ancient California). Editing and notes by $M$. Leon-Portilla, from the original manuscript written by del Barco in the 18 th century, Universidad Nacional Autonoma de Mexico (UNAM), Mcxico City, $467 \mathrm{pp}$.

Bouchon-Brandeley M. (1885) La péche et la culture des huitres perlières à Tahiti. In Pêcheries de l'Archipiel Tuamotu, Ministère de la Marine et des Colonies, Imprimerie du Journal Officicl, $209 \mathrm{pp}$.
Californiana I: Documentos para la Historia de la Demarcación Comercial de California (1583-1633): Real Cédula a Favor de Hernando de Santotis: 15 de lunio de 1596 (Documents for the History of the Commcreial Demarcation of California [1583-1633]: Royal Decree to Hernando de Santotis: June 15, 1596), Vol. 1. Editing and notes by M. Mathcs, José Porrua Editorial, Madrid, Spain, 1965, pp. 14-20.

Californiana III: Documentos para la Historia de la Transformación Colonizadora de California (1679-1686) Año de 1686: Testimonio de Autos de la Ultima Entrada que Hizo en las Islas de las Californias el Alminante I. Atondo y Antillón y de la Ultima Resolución de Dicha Conversion (Documents for the History of the Colonizing Transition of California [1679-1686]: Testimony of the Last Entrance that Admiral 1. Atondo y Antillón Made in California and the Last Resolution Taken on that Conversion), Vol. L. Editing and notes by M. Mathes, José Porrua Editorial, 1974, Madrid, Spain, pp. 756-767.

Cariño M. (1990) Mito y perlas en California (1530-1830) (Myth and pearls in California (1530-1830]). Sociales y Humanidades, Revista del Area Interdisciplinaria de Ciencias Sociales y Humanidades, Universidad Autónoma de Baja Califonnia Sur (UABCS), La Paz, Mexico, pp, 53-59.

Carino M. (1994) Natural pearl farming in the early century at Bahía de La Paz, South Baja California, Mexico. Journal of Shellfish Research, Vol. 13, No. 1, pp. 346-347.

Cariño M., Cáceres C. (1990) La perlicultura cn la península de Baja California a principios de siglo (Pcarl culture in the peninsula of Baja California at the beginning of the century). Serie Cientifica, Vol. 1, Special Number AMAC 1, UABCS, La Paz, Mexico, pp. 2-4.

Clavijcro F.X. (1789) Historia de la Antigua Baja California (History of Ancient Baja California). Editing and notes by M. León-Portilla, Editorial Porría, Mexico City, 1990, 262 pp.

Coeroli M. (1994) Tahiti culturcd pcarl. Proceedings of the International Pearl Conference and Pearl Exposition '94, May 14-19, Honolulu, Hawaii.

Crossland C. (1931) The pearl shell farm at Dongonab on the Red Sea. Sudan Notes and Records, Vol. 14, Part 2, pp. $163-170$.

Crossland C. (1956) The cultivation of the mother of pearl oyster in the Red Sea. As reprinted in the Australian Jommal of Marine and Freshwater Research, Vol. 8, No. 2, pp. 11-130.

Crosby H. (1982) Manuel de Ocio: Primer millonario de las Californias (Manucl de Ocio: First millionaire of the Californias!. In Proceedings of the 20th Symposimn of the Asociación Cultural de las Californias, May 1982, Tecate, Baja California, pp. 1-5.

Diguet L. (1895) Pêche de l'huître perlière dans le Golfe de Californic. Bulletin de la Société Centrale d'Acluiculture de France, Vol. 8, No. 1-2, Paris, pp. 3-18. 
Diguet L. (1919) Culture de l'huître perlière dans le Golfe de Californie. Bulletin de la Société Nationale d'Acclimatation de France, Paris, France, pp. 1-15.

Esteva J.M. (1857) Memoria sobre la pesca de la perla en la Baja Calfiornia: 1857 (Memoirs on pearl fishing in Baja California). In Las Perlas de Baja California, Ministry of Fisheries, Mexico, 1977, pp. 10-15.

Estrada G. (1977) El cultivo y la explotación de la concha perla en la costa mexicana del Pacífico (Cultivation and exploitation of mother-of-pearl in the Mexican Pacific coast). In Las Perlas de Baja California, Ministery of Fisheries, Mexico, pp. 10-15.

Gerhard P. (1956) Pearl Diving in lower California, 1535-1830. Pacific Historic Review, Vol. 25, No. 3, pp. 239-249.

Hornell J. (1905) The biological results of the Ceylon pearl fishery of 1904. Reports from the Ceylon Marine Biological Laboratory, No. 1, printed by George T. A. Skeen, Gov. Printer, Ceylon

Jameson L.H. (1912) An examination of the causes which have led to the failure of the biological work recently undertaken on the Ceylon pearl fisheries. Journal of Economic Biology, Vol. 7, No. 1, pp. 10-22.

Jameson L.H. (1914) The pearling industry: A chapter in economic biology. Scientific American Supplement, No. 1983, January, pp. 12-16.

Keen M. (1971) Sea Shells of Tropical West America. Stanford University Press, Palo Alto, California.

Kunz G.F., Stevenson C.H. $(1908)$ The Book of the Pearl. Century Co., New York.

Levi P., Poirot J.P. (1992) Perles fines d'hier et d'aujourd'hui. Nacres et Perles, Bulletin of the Oceanographic Institute of Monaco, Special No. 8, pp. 113-114.

Mathes M. (1973) Sebastián Vizcaíno y la Expansión Española en el Océano Pacifico: 1580-1630 (Sebastián Vizcaíno and Spanish Expansion in the Pacific Ocean). Instituto de Investigaciones Históricas de la UNAM, Mexico City.

Meade A.W. (1984) El nombre California (The name California). Calafia, Vol. 5, No. 2, pp. 15-23.

Monteforte M. (1990) Ostras perleras y perlicultura: Situación actual en los principales paises productores y perspectivas para México (Pearl oysters and pearl culture: Current situation in the principal producing countries and prospects for Mexico). Serie Cientifica, Vol. 1, Special Number AMAC I, UABCS, La Paz, Mexico, pp. 13-18.

Monteforte M. (1994) Perspectives for the installation of a pearl culture enterprise in Bahía de La Paz, South Baja California, Mexico. Joumal of Shellfish Research, Vol. 13, No. 1, pp. 339-340.

Monteforte M., Aldana C. (1994) Spat collection, growth and survival of pearl oyster Pteria sterna under extensive culture conditions in Bahia de La Paz, South Baja California, Mexico. Journal of Shellfish Research, Vol. 13, No. 1, pp. 340-341.

Monteforte M., Bervera H. (1994) Spat collection trials of pearl oyster Pinctada mazatlanica and Pteria sterna in Bahia de La Paz, South Baja California, Mexico. Journal of Shellfish Research, Vol. 13, No. 1, pp. 343-347.

Monteforte M., Bervera H., Morales S. (1994a) Growth and survival of pearl oyster Pinctada mazatlanica in extensive conditions at Bahía de La Paz, South Baja California, Mexico. Journal of Shellfish Research, Vol. 13, No. 1, pp. 343-344.

Monteforte M., Bervera H., Morales S., Pérez V., Saucedo P., Wright H. (1994b) Results of the production of cultured pearls in Pinctada mazatlanica and Pteria sterna from Bahia de La Paz, South Baja California, Mexico. Iournal of Shellfish Research, Vol. 13, No. 1, pp. 344-345.

Monteforte M., Carin̄o M. (1992) Exploration and evaluation of natural stocks of pearl oysters Pinctada mazatlanica and
Pteria sterna (Bivalvia: Pteridae): La Paz Bay, South Baja California, Mexico. AMBIO Journal of the Human Environment, Vol. 21, No. 14, pp. 314-320.

Monteforte M., García-Gasca A. (1994) Spat collection studies on pearl oyster Pinctada mazatlanica and Pteria sterna (Bivalvia: Pteridae) in Bahia de La Paz, South Baja California, México. Hydrobiologia, No. 291, pp. 21-34.

Monteforte M., Wright H. (1994) Ecology of pearl oyster spat collection in Bahia de La Paz, South Baja California, Mexico: temporal and vertical distribution, substrate selection, associated species. Journal of Shellfish Research, Vol. 13, No. 1, pp. 342-343.

Mosk S.A. (1927) Spanish Voyages and Pearl Fisheries in the Gulf of California: A Study in Economic History. Ph.D. thesis in economics-geography, University of California at Berkeley, 343 pp.

Mosk S.A. (1941) Capitalistic development in the lower California pearl fisheries. Pacific Historic Review, Vol. 10, pp. $461-468$.

Navarro G.L. (1964) Don José de Gálvez y la Comandancia General de las Provincias Internas del Norte de la Nueva España (Don José de Galvez and the General Command of the Internal Provinces of the North of New Spain). Escuela de Estudios Hispanoamericanos de Sevilla, Seville, Spain, $764 \mathrm{pp}$.

Ranson G. (1955) Rehabilitation of pearl oyster beds in French Oceania. Quarterly Bulletin of the South Pacific Commission, Vol. 5, No. 3, pp. 22-24.

del Río I. (1985) A la Diestra Mano de las Indias (Towards the "Right Hand" of the Indies). Gobierno del Estado de Baja Califormia Sur, La Paz, Mexico, 128 pp.

Taburiaux J.(1983) La Perle et ses secrets . . . Hemmerlé Petit et Cie., Paris. France, 252 pp.

Toulemont A. (1992) Avant-propos. Nacres et Perles, Bulletin de l'Institut Océanographique de Monaco, Special No. 8, pp. iv-ix.

Townsend C. $\{1889\}$ Report on the pearl fishery of the Gulf of California. Bulletin of the United States Fish Commission, No. 9, pp. 85-90.

Townsend C. (1911) Voyage of the "Albatross" to the Gulf of California. Bulletin of the Museun of Natural History, No. 35, pp. 35-39.

Vives G. (1908) Criaderos de Concha Madre Perla en Baja California (Mother-of-Pearl Nurseries in Baja California). Report to the Secretaría de Fomento, Bulletin of the Secretaría de Fomento, No. 6., Mexico. Document found in the library archives of the Laboratoire de Biologie de Invertebrés Marins et Malacologie, Muséum National d'Histoire Naturelle, Paris, France, $67 \mathrm{pp}$.

Vives G. (1917-1919) Informes sobre la Companiia Criadora de Concha y Perla de la Baja California, S.A. (Reports about the Compañía Criadora de Concha y Perla de la Baja Californial. Report to the Secretaría de Fomento, Mexico (originals from the Vives family|, $38 \mathrm{pp}$.

Vives G. (1914) Original of a letter sent by Gastón Vives to Léon Diguet, describing his escape from La Paz in 1914. Document found in the library archives of the Laboratoire de Biologie de Invertebrés Marins et Malacologie, Muséum National d'Histoire Naturelle, Paris, France, $3 \mathrm{pp}$.

Vives G. (1918) Memorandum sobre la incautación, destrucción y renacimiento de la "Compañía Criadora de Concha y Perla de la Baja California, S.A". (Memorandum describing the confiscation, destruction and revival of the Compañía Criadora de Concha y Perla de Baja California, S.A.). Document found in the archives of the library of the Laboratoire de Biologie de lnvertebrés Marins et Malacologie, Muséum National d'Histoire Naturelle, Paris, France, $9 \mathrm{pp}$. 